\title{
PENGARUH UKURAN PERUSAHAAN, FINANCIAL LEVERAGE, MANAJEMEN MODAL KERJA TERHADAP PROFITABILITAS PERUSAHAAN SEKTOR INDUSTRI BARANG KONSUMSI
}

\author{
Ni Luh Ayu Megawati ${ }^{1}$ \\ Ida Bagus Panji Sedana ${ }^{2}$ \\ ${ }^{1,2}$ Fakultas Ekonomi dan Bisnis Universitas Udayana (Unud), Bali, Indonesia \\ e-mail: ayumegawati05@yahoo.com
}

\begin{abstract}
ABSTRAK
Penelitian ini bertujuan untuk menganalisis signifikansi pengaruh ukuran perusahaan, financial leverage, dan manajemen modal kerja terhadap profitabilitas. Penelitian ini dilakukan pada Perusahaan Sektor Industri Barang Konsumsi yang terdaftar di Bursa Efek Indonesia (BEI) periode 2015-2017. Jumlah sampel penelitian ini adalah 27 perusahaan, dengan metode purposive sampling method. Pengumpulan data dilakukan dengan metode observasi non partisipan yaitu melalui data laporan keuangan yang dipublikasikan. Didasarkan hasil analisis ditemukan bahwa ukuran perusahaan mempengaruhi positif serta signifikan pada profitabilitas. Financial leverage mempengaruhi negatif dan signifikan pada profitabilitas. Manajemen modal kerja berpengaruh positif serta tidak signifikan pada profitabilitas. Hal ini menunjukkan bahwa perusahaan harus memperhatikan ukuran perusahaan dan financial leverage dalam mengambil keputusan investasi serta keputusan pendanaan.
\end{abstract}

Kata kunci: profitabilitas, ukuran perusahaan, financial leverage, manajamen modal kerja

\begin{abstract}
This study aims to analyze the significance of the influence of company size, financial leverage, and working capital management on profitability. This research was conducted at the Consumer Goods Industry Sector Company listed on the Indonesia Stock Exchange (IDX) for the 2015-2017 period. The number of samples of this study were 27 companies, using the purposive sampling method. Data collection is done by non-participant observation method, namely through published financial report data. Based on the results of the analysis it was found that the size of the company had a positive and significant effect on profitability. Financial leverage has a negative and significant effect on profitability. Working capital management has a positive and not significant effect on profitability. This shows that companies must pay attention to company size and financial leverage in making investment decisions and funding decisions.

Keywords: profitability, company size, financial leverage, working capital management
\end{abstract}




\section{PENDAHULUAN}

Pada umumnya suatu perusahaan akan berusaha untuk mencapai tujuannya, baik tujuan jangka pendek maupun tujuan jangka panjang. Salah satu tujuan jangka pendek perusahaan adalah memenuhi kebutuhan konsumen akan produknya dan mempertahankan eksistensi perusahaan dengan cara meningkatkan seluruh aktivitas perusahaan dan mengoptimalkan sumber daya yang dimiliki agar perusahaan mencapai laba yang maksimal (Yanthi \& Sudiartha, 2017). Laba dapat dimaksimalkan dengan adanya peningkatan penjualan produk dan meminimalkan biaya operasional perusahaan. Efisiensi aktivitas perusahaan untuk memperoleh laba bisa diukur memakai rasio profitabilitas.

Profitabilitas merupakan kemampuan perusahaan mendapatkan laba pada hubungannya dengan penjualan, total aktiva maupun modal pribadi. Profitabilitas sangatlah penting bagi investor dalam menilai kinerja suatu perusahaan (Sartono,

2010:122). Profitabilitas menunjukkan kemampuan perusahaan dalam memperoleh keuntungan dan tingkat pengembalian yang akan diterima oleh investor. Profitabilitas menggambarkan apakah suatu perusahaan memiliki peluang atau prospek yang baik di masa mendatang. Semakin tinggi profitabilitas suatu perusahaan, maka kemampuan perusahaan dalam mempertahankan kelangsungan hidupnya akan semakin terjamin (Hermuningsih, 2013).

Terdapat alat pengukur digunakan guna mengukur tingkat profitabilitas, yaitu return on assets (ROA), return on equity (ROE), profit margin dan earning per share (EPS). Penelitian ini mengukur profitabilitas dengan menggunakan Return on Assets (ROA). ROA merupakan salah satu rasio profitabilitas yang dapat mengukur kemampuan menghasilkan laba dari total aktiva yang digunakan (Wiagustini, 2014:90). Rasio ini melihat sejauh mana investasi yang telah ditanamkan mampu memberikan pengembalian keuntungan sesuai dengan yang diharapkan, dan investasi tersebut sama dengan asset perusahaan yang ditanamkan atau ditempatkan (Fahmi, 2016:82).

Profitabilitas tinggi bisa mendukung kegiatan operasional perusahaan dengan maksimal. Banyak faktor mempengaruhi rendah tinggi profitabilitas, yaitu ukuran perusahaan, leverage, dan manajemen modal kerja (Pangestuti \& Oetomo, 2016). Ukuran perusahaan merupakan faktor penting dalam menentukan profitabilitas. Ukuran perusahaan pada dasarnya mengelompokkan perusahaan ke dalam perusahaan besar, sedang dan kecil (Daniel \& Sedana, 2017). Ukuran perusahaan mencakup besar kecilnya sebuah perusahaan yang diperlihatkan oleh aset, jumlah penjualan, rata-rata total penjualan dan rata-rata total aset. Semakin besar suatu perusahaan maka total aset bisa dipakai guna mempenuhi permintaan produk akibatnya profit perusahaan bisa meningkat (Dewi \& Badjra, 2017).

Penelitian mengenai pengaruh ukuran perusahaan terhadap profitabilitas telah banyak dilakukan dan masih terdapat kontroversi, sehingga perlu adanya penelitian lebih lanjut mengenai hal tersebut. Penelitian yang dilakukan oleh Yazdanfar (2013), Al-Jafari \& Al Samman, (2015) serta Isık (2017) menyatakan jika ukuran perusahaan mempengaruhi positif dan signifikan pada profitabilitas perusahaan. Pernyataan tersebut mendapat dukungan dari Yazdanfar \& Öhman (2014), Sritharan (2015) serta Sarwat (2017) yang menemukan hasil yang sama. Bertentangan dengan penelitian tersebut, Mwangi \& Murigu (2015), Margaretha 
\& Supartika (2016) serta Meidiyustiani, (2016) menemukan bahwa ukuran perusahaan mempengaruhi secara negatif serta signifikan pada profitabiitas.

Leverage ialah penggunaan assets serta sumber dana (sources of fund) oleh perusahaan yg memiliki biaya tetap (beban tetap) dalam tujuan supaya menambah keuntungan potensial pemegang saham (Sartono, 2010:257). Leverage dapat dikatakan sebagai suatu rasio keuangan yang mengukur berapa jauh perusahaan didanai oleh modal pinjaman (Wiagustini, 2014:88). Financial leverage adalah penggunaan sumber dana yang memiliki beban tetap dengan harapan bahwa akan memberikan tambahan keuntungan yang lebih besar daripada beban tetapnya sehingga akan meningkatkan keuntungan yang tersedia bagi pemegang saham (Sartono, 2010:257). Yang membahayakan perusahaan ialah penggunaan utang yg terlalu tinggi karena perusahaan masuk kategori extreme leverage (utang ekstrim) ialah perusahaan terjebak dlm tingkat hutang yg tinggi dan sulit melepaskan dari beban hutang itu (Fahmi, 2016:72). Dengan demikian, perusahaan akan mengalami penurunan profit karena penggunaan utang yang terlalu tinggi.

Beberapa hasil diperoleh dari penelitian dilaksanakan sebelumnya oleh Alghusin (2015) serta Lazar (2016) dan mendapatkan hasil jika financial leverage memiliki pengaruh negatif serta signifikan terhadap profitabilitas perusahan. Hasil yang berlawanan ditemukan Kartikasari \& Merianti (2016) dan Rudin, et al. (2016) menemukan bahwa financial leverage mempengaruho positif serta signifikan pada profitabilitas perusahaan. Beda dgn hasil penelitian itu, Fareed, et al. (2017) dan Winarno dkk. (2015) menemukan bahwa financial leverage berpengaruh negatif dan tidak signifikan terhadap profitabilitas perusahaan sedangkan Jacob (2016) menemukan bahwa financial leverage berpengaruh positif dan tidak signifikan terhadap profitabilitas perusahaan.

Manajemen modal kerja berkaitan dengan investasi pada aktiva lancar dan hutang lancar, terutama mengenai bagaimana menggunakan dan komposisi keduanya akan mempengaruhi risiko (Wiagustini, 2014:129). Modal kerja adalah investasi sebuah perusahaan pada aktiva-aktiva jangka pendek, seperti kas, sekuritas, persediaan dan piutang (Fahmi, 2016:100). Manajemen modal kerja yang efektif sangatlah penting dalam kelangsungan pertumbuhan perusahaan untuk jangka panjang. Apabila perusahaan mengalami kekurangan modal kerja untuk meningkatkan volume penjualan dan produksinya, maka kemungkinan perusahaan akan kehilangan kesempatan memperoleh keuntungan (Wiagustini, 2014:120).

Hidayat dan Wahyuati (2015) menemukan bahwa manajemen modal kerja memiliki pengaruh positif dan signifikan terhadap profitabilitas. Penelitian lain yang dilakukan oleh Chen \& Oetomo (2015) serta Sariyana, dkk. (2016) juga mendapatkan hasil yang sama. Hal yang lain ditemukan oleh Santi \& Utiyati, (2017) yang mengemukakan bahwa manajemen modal kerja mempengaruhi positif serta tak signifikan pada profitabilitas perusahaan.

Penelitian ini dilakukan di perusahaan manufaktur sektor industri barang konsumsi pada Bursa Efek Indonesia (BEI). Persaingan dalam sektor industri manufaktur di Indonesia semakin meningkat, hal ini dapat kita lihat dari jumlah perusahaan manufaktur sektor industri barang konsumsi yang cukup banyak serta dari banyaknya produk impor dan produk-produk ilegal yang mudah masuk ke 
Indonesia. Hal tersebut menjadi hambatan bagi perusahaan manufaktur dalam negeri untuk menguasai pasar. Dengan demikian, perusahaan harus mampu mengelola keuangan perusahaan dengan baik agar mampu menjamin keberlangsungan usaha perusahaan.

Perusahaan-perusahaan manufaktur sektor industri barang konsumsi dibagi menjadi enam subsektor yaitu subsektor makanan dan minuman, subsektor rokok, subsektor, subsektor farmasi, subsektor kosmetik dan barang keperluan rumah tangga, subsektor perlatan rumah tangga serta subsektor lain-lain. Berikut disajikan rata-rata Return on Assets (ROA) perusahaan sektor industri barang konsumsi di BEI per sub sektor periode 2015-2017.

\section{Tabel 1.}

\section{Rata-rata Return on Assets (ROA) Perusahaan Sektor Industri Barang} Konsumsi di BEI per Subsektor Periode 2015-2017

\begin{tabular}{clccc}
\hline \multirow{2}{*}{ Nub Sektor } & \multicolumn{3}{c}{ Tahun } \\
\cline { 3 - 5 } No. & \multicolumn{2}{c}{$\mathbf{( \% )}$} & $\mathbf{( \% )}$ & $\mathbf{( \% )}$ \\
\hline 1. & Subsektor Makanan dan Minuman & $\mathbf{2 0 1 5}$ & $\mathbf{2 0 1 6}$ & $\mathbf{2 0 1 7}$ \\
2. & Subsektor Rokok & 6.56 & 8.80 & 7.58 \\
3. & Subsektor Farmasi & 8.56 & 8.25 & 10.22 \\
& Subsektor Kosmetik dan Barang Keperluan & & & \\
4. & Rumah Tangga & 12.44 & 9.75 & 8.19 \\
5. & Subsektor Peralatan Rumah Tangga & -0.50 & 2.09 & 3.07 \\
6. & Subsektor Lain-Lain & 0 & 0 & 7.78 \\
\hline
\end{tabular}

Sumber: www.idx.co.id (data diolah), 2018

Berdasarkan Tabel 1. dapat disimpulkan bahwa rata-rata Return on Assets perusahaan sektor industri barang konsumsi mengalami fluktuasi selama periode 2015-2017. ROA pada subsektor makan dan minuman dan subsektor rokok mengalami fluktuasi selama periode penelitian. ROA pada subsektor farmasi dan subsektor kosmetik dan barang keperluan rumah tangga cenderung mengalami penurunan sedangkan subsektor peralatan rumah tangga mengalami peningkatan selama periode penelitian.

Ukuran perusahaan menggambarkan besar kecilnya suatu perusahaan. Perusahaan dengan ukuran besar biasanya lebih gampang guna mendapat dana pinjaman pada jumlah cukup besar dan membantu kegiatan operasional dari perusahaan (Sartono, 2010:249). Hal ini mengakibatkan produktivitas perusahaan tumbuh sehingga profit perusahaan bisa meningkat (Putra \& Badjra, 2015). Semakin besar ukuran perusahaan, jadi semakin besar total aset bisa dipakai guna memenuhi permintaan produk kemudian profit perusahaan dapat meningkat.

Penelitian mengenai pengaruh ukuran perusahaan pada profitabilitas yang dilaksanakan oleh Lokollo (2013), Barus \& Leliani (2013) dan Ambarwati dkk. (2015) menyatakan jika ukuran perusahaan mempengaruhi positif serta signifikan pada profitabilitas perusahaan. Kemudian pernyataan itu juga sejalan dengan Iqbal \& Zhuquan (2015), Nejad et al. (2015), serta Sarwat (2017) yang menemukan hasil yang sama. Daniel \& Sedana (2017) dan Hantono (2017) juga menemukan 
bahwa ukuran perusahaan memiliki pengaruh positif serta signifikan pada profitabilitas. Dengan penjelasan di atas serta hasil penelitian sebelumnya, hipotesis yg diajukan ialah:

$\mathrm{H}_{1}$ : Ukuran perusahaan berpengaruh positif dan signifikan terhadap profitabilitas.

Leverage ialah mengukur sampai mana perusahaan dibiayai menggunakan hutang. Financial leverage adalah penggunaan sumber dana yang memiliki beban tetap dengan harapan bahwa akan memberikan tambahan keuntungan yang lebih besar daripada beban tetapnya sehingga akan meningkatkan keuntungan yang tersedia bagi pemegang saham. Financial Leverage menunjukkan proporsi atas penggunaan hutang untuk membiayai investasinya. Penggunaan hutang yang terlalu tinggi akan membahayakan perusahaan karena perusahaan akan masuk dalam kategori extreme leverage (hutang ekstrim) yaitu perusahaan terjebak dalam tingkat hutang yang tinggi dan sulit untuk melepaskan beban hutang tersebut (Fahmi, 2016:72). Suatu perusahaan yang terlalu tinggi melakukan pendanaan aset dari hutang dapat menyebabkan semakin tinggi debt to total asset yang berarti semakin tinggi risiko keuangannya sehingga kemampuan perusahaan untuk mendapatkan keuntungan akan menurun.

Penelitian yang dilaksanakan sebelumnya oleh Alghusin (2015) serta Isık (2017) mendapatkan hasil jika financial leverage memiliki pengaruh negatif dan signifikan terhadap profitabilitas perusahan. Lazar (2016), Kartikasari \& Merianti (2016) kemudian Nejad et al. (2015) juga menemukan jika financal leverage memiliki pengaruh negatif serta signifikan pada profitabilitas. Dengan penjelasan di atas serta hasil penelitian sebelumnya, hipotesis yg diajukan ialah:

$\mathrm{H}_{2}$ : Financial leverage berpengaruh negatif dan signifikan terhadap profitabilitas.

Modal kerja adalah investasi sebuah perusahaan pada aktiva-aktiva jangka pendek, misalnya kas, sekuritas, persediaan dan piutang (Fahmi, 2016:100). Modal kerja dibutuhkan perusahaan dalam membiayai kegiatan operasional seluruhnya. Jika perusahaan mengalami kekurangan modal kerja untuk memperluas penjualan serta meningkatkan produksinya, maka kemungkinan besar perusahaan akan kehilangan pendapatan dan keuntungannya.

Penelitian yang dilakukan sebelumnya oleh Suryaputra \& Christiawan (2016), Pangestuti \& Oetomo (2016) serta Puspita \& Hartono (2018) menemukan bahwa manajemen modal kerja memiliki pengaruh positif dan signifikan terhadap profitabilitas. Hasil penelitian yang sama juga dikemukakan oleh Ambarwati dkk. (2015) dan Sariyana dkk. (2016). Berdasarkan penjelasan di atas serta hasil penelitian sebelumnya, hipotesis yg diajukan ialah:

$\mathrm{H}_{3}$ : Manajemen modal kerja berpengaruh positif dan signifikan terhadap profitabilitas. 


\section{METODE PENELITIAN}

Penelitian ini dilakukan dengan memakai pendekatan kuantitatif dan bersifat asosiatif-kausalitas. Lokasi penelitian ini dilakukan pada perusahaan sektor industri barang konsumsi di Bursa Efek Indonesia (BEI). Obyek yang diteliti dalam penelitian ini adalah profitabilitas perusahaan sektor industri barang konsumsi di Bursa Efek Indonesia (BEI) selama periode 2015-2017. Variabel yang diteliti dalam penelitian ini adalah variabel terikat/dependen yaitu return on asset (ROA) (Y), variabel bebas/independen yaitu Ukuran perusahaan $\left(\mathrm{X}_{1}\right)$, Financial Leverage $\left(\mathrm{X}_{2}\right)$. Manajemen Modal Kerja $\left(\mathrm{X}_{3}\right)$. Populasi penelitian ialah kesemua perusahaan sektor industri barang konnsumsi di BEI periode 2015-2017 berjumlah sebanyak 45 perusahaan. Kriteria untuk pemilihan sampel akan diteliti pada penelitian ini ialah pertama, perusahaan sektor industri barang konsumsi yg terdaftar berturut-turut di Bursa Efek Indonesia pada periode 2015-2017. Kedua, perusahaan sektor industri barang konsumsi yang mempublikasikan laporan keuangannya secara lengkap selama periode penelitian. Ketiga, perusahaan sektor industri barang konsumsi yang tidak memiliki profit negatif selama periode penelitian. Pada Tabel 2. perusahaan sektor industri barang konsumsi yang terdaftar di BEI pada periode 2015-2017 berjumlah 45 perusahaan.

Tabel 2.

Proses Seleksi Perusahaan Sampel

\begin{tabular}{lc}
\multicolumn{1}{c}{ Keterangan } & Jumlah Perusahaan \\
\hline Perusahaan yang listing di BEI (populasi) & 45 \\
$\begin{array}{l}\text { Perusahaan yang tidak terdaftar berturut-turut di BEI } \\
\text { periode 2015-2017 }\end{array}$ & $(6)$ \\
$\begin{array}{l}\text { Perusahaan yang tidak mempublikasikan laporan keuangan } \\
\text { secara lengkap }\end{array}$ & $(1)$ \\
Perusahaan yang memiliki profit negatif & \\
Total Sampel & 27 \\
\hline
\end{tabular}

Sumber: Data diolah, 2018

Data kualitatif pada penelitian ialah daftar nama perusahaan sektor industri barang konsumsi di BEI periode 2015-2017. Data kuantitatif dalam penelitian ini yaitu rasio atau angka keuangan yang terdapat dalam laporan keuangan utk mengetahui profitabilitas, ukuran perusahaan, financial leverage, serta manajemen modal kerja perusahaan sektor industri barang konsumsi di BEI periode 20152017. Data sekunder yang digunakan dalam penelitian ini berasal dari situs resmi BEI untuk memperoleh laporan keuangan perusahaan. Metode pengumpulan data yg dipakai dalam penelitian ialah metode observasi non-partisipan. Data penelitian dikumpulkan dengan cara menganalisis laporan keuangan tahunan perusahaan sektor industri barang konsumsi di BEI periode 2015-2017.

Teknik analisis data yang digunakan dalam penelitian ini adalah metode analisis regresi linier berganda yang dilakukan dengan bantuan program SPSS 
13.0 for windows. Menurut Sugiyono (2016:283) persamaan regresi linier berganda ditunjukkan oleh persamaan sebagai berikut:

$\mathrm{Y}=\mathrm{a}+\mathrm{b}_{1} \mathrm{X}_{1}+\mathrm{b}_{2} \mathrm{X}_{2}+\mathrm{b}_{3} \mathrm{X}_{3}+\mathrm{e}$

Keterangan:

$\mathrm{Y}=$ Profitabilitas

$\mathrm{a}=$ Konstanta

$\mathrm{b}_{1-3}=$ Koefisien regresi masing-masing variabel bebas

$\mathrm{X}_{1}=$ Ukuran perusahaan

$\mathrm{X}_{2}=$ Financial Leverage

$\mathrm{X}_{3}=$ Manajemen modal kerja

$\mathrm{e} \quad=$ Faktor gangguan pada observasi

Uji asumsi klasik digunakan karena penelitian ini akan menggunakan analisis linier berganda dalam mencari signifikansi pengaruh hubungan antar variabel. Uji asumsi klasik terbagi atas beberapa uji. 1). Uji normalitas adalah suatu uji statistik yang bertujuan untuk mengetahui distribusi data variabel yang akan digunakan dalam penelitian adalah data yang berdistribusi nomal. Metode yang digunakan adalah dengan melihat hasil statistik Kolmogorov-Smirnov. Apabila nilai signifikansi $>0,05$ berarti data residual berdistribusi normal, sedangkan nilai signifikansi $<0,05$ berarti data residual berdistribusi tidak normal. 2). Uji autokorelasi bertujuan untuk menguji apakah dalam model regresi liner ada korelasi auto atau pengaruh pengamatan sebelumnya dalam model regresi.

Uji autokorelasi dapat dilakukan dengan menggunakan Uji Durbin-Watson (DW-test). Dalam uji DW ini, apabila diperoleh hasil $\mathrm{dU}<\mathrm{dW}<(4-\mathrm{dU})$ maka tidak terdapat autokorelasi baik positif maupun negati atau dapat dikatakan bebas di dalam model persamaan regresi. 3). Uji multikolinearitas bertujuan untuk menguji apakah pada model regresi ditemukan adanya korelasi antar variabel bebas. Pendektesian korelasi antar variabel bebas dapat dilihat dari tolerance value dan Varians Inflation Factor (VIF). Jika tolerance value lebih tinggi dari 0,1 atau VIF lebih kecil dari 10 maka dikatakan tidak ada multikolinearitas. 4). Uji heteroskedastisitas mempunyai tujuan guna menguji apabila $\mathrm{dlm}$ model regresi terjadi ketidakserupaan varians dari residual satu pengamatan ke pengamatan yang lain. Uji heteroskedastisitas bisa dilakukan dengan Uji Glejser, yaitu dgn melihat nilai signifikansi. Bila tingkat signifikansi terdapat di atas 0,05 kemudian model regresi ini bebas dari masalah heteroskedastisitas.

Koefisien determinasi $\left(\mathrm{R}^{2}\right)$ memiliki tujuan guna mengukur seberapa jauh kemampuan model dalam menjelaskan variasi variabel dependen atau dapat dikatakan besarnya peranan variabel $\mathrm{X}$ terhadap variabel $\mathrm{Y}$. Nilai $\mathrm{R}^{2}$ terletak antara 0 sampai dengan 1 . Nilai $\mathrm{R}^{2}$ yang kecil berarti kemampuan dari variabel independen dalam menjelaskan variasi variabel dependen sangat terbatas. Apabila $\mathrm{R}^{2}$ tinggi atau mendekati satu atau sama dengan satu berarti variabel independen mampu sepenuhnya menjelaskan variabel dependen. Uji t dipakai utk mengetahui pengaruh dari masing-masing variabel independen pada variabel dependen. Kriteria penilaian dilaksanakan dgn melihat hasil regresi dgn program SPSS, ialah di bandingkan tingkat dari signifikan masing-masing variabel bebas dgn $\alpha=0,05$. 
Apabila tingkat signifikansi $\mathrm{t} \leq \alpha=0,05$, maka $\mathrm{H}_{1}$ diterima dan $\mathrm{H}_{0}$ ditolak. Namun, bila tingkat signifikansi $\mathrm{t} \geq \alpha 0,05$ maka $\mathrm{H}_{1}$ ditolak dan $\mathrm{H}_{0}$ diterima. Uji $\mathrm{F}$ bertujuan untuk mengetahui kelayakan model regresi linier berganda sebagai alat analisis yang menguji pengaruh variabel bebas yaitu, ukuran perusahaan $\left(\mathrm{X}_{1}\right)$, leverage $\left(\mathrm{X}_{2}\right)$, dan manajemen modal kerja $\left(\mathrm{X}_{3}\right)$ terhadap variabel terikat yaitu profitabilitas (Y) dengan $\alpha=0,05$. Uji F dapat diterima apabila nilai signifikansi pada $\mathrm{F}$ hitung lebih kecil daripada taraf signifikansi $\alpha=0,05$.

\section{HASIL DAN PEMBAHASAN}

Bursa Eefek Indonesia (BEI) merupakan bursa hasil penggabungan dari Bursa Efek Jakarta (BEJ) dengan Bursa Efek Surabaya (BES). Semua perusahaan publik yang mencatatkan sahamnya di BEI diklasifikasikan ke dalam 9 sektor yaitu: sektor pertanian, sektor pertambangan, sektor industri dasar dan kimia, sektor aneka industri, sektor industri barang konsumsi, sektor properti, real estate dan konstruksi bangunan, sektor infrastruktur, utilitas dan transportasi, sektor keuangan serta sektor perdagangan, jasa dan investasi.

Sektor industri barang konsumsi merupakan industri yang tidak lepas dari kehidupan sehari-hari masyarakat, sehingga perusahaan yang termasuk dalam sektor ini mampu bertahan dalam dunia industri untuk waktu yang lama. Barang konsumsi merupakan barang yang dipakai secara langsung atau tidak langsung oleh konsumen untuk keperluan pribadi atau rumah tangga yang sifatnya sekali pakai atau barang yang dibeli untuk konsumsi akhir. Sektor industri barang konsumsi terbagi menjadi enam subsektor yaitu: subsektor makanan dan minuman, subsektor rokok, subsekor farmasi, subsektor kosmetik dan barang keperluan rumah tangga, subsektor peralatan rumah tangga dan subsektor lainnya.

Pada penelitian ini data dari populasi perusahaan yang tergolong perusahaan sektor industri barang konsumsi pada Bursa Efek Indonesia tahun 2015-2017 berjumlah 45. Populasi tersebut diseleksi kembali berdasarkan purposive sampling method dengan kriteria ketentuan sehingga diperoleh sampel berjumlah 27 perusahaan. Pada saat dilakukan analisis data, terdapat 3 perusahaan yang memiliki data dengan nilai-nilai ekstrim. Nilai ekstrim yang dimaksud adalah nilai yang jauh berbeda dengan sebagian nilai yang terdapat dalam sampel. Perusahaan tersebut adalah PT Budi Starch \& Sweetener Tbk, PT Multi Bintang Indonesia Tbk, dan Unilever Indonesia Tbk, sehingga total sampel yang digunakan dalam penelitian ini menjadi 24 perusahaan.

Analisis statistik deskriptif memberikan gambaran atau deskripsi mengenai seluruh variabel yang diteliti. Bab sebelumnya telah menjelaskan bahwa penelitian ini bertujuan untuk mengetahui Pengaruh Ukuran Perusahaan, Leverage, dan Manajemen Modal Kerja terhadap Profitabilitas Pada Perusahaan Sektor Industri Barang Konsumsi Di BEI periode tahun 2015 hingga 2017. Berdasarkan data laporan keuangan, diperoleh hasil analisis statistik deskriptif sebagai berikut. 
Tabel 3.

Hasil Analisis Statistik Deskriptif

\begin{tabular}{lccccc}
\hline & N & Minimum & Maximum & Mean & $\begin{array}{c}\text { Std. } \\
\text { Deviation }\end{array}$ \\
\hline Profitabilitas & 72 & $1.6 \%$ & $30 \%$ & $10.443 \%$ & $6.3500 \%$ \\
Ukuran Perusahaan & 72 & 25.796 & 32.108 & 28.79000 & 1.560220 \\
Financial Leverage & 72 & $7.1 \%$ & $63.2 \%$ & $34.685 \%$ & $14.0077 \%$ \\
Manajemen Modal Kerja & 72 & .729 & 37.319 & 5.62278 & 6.577094 \\
Valid N (listwise) & 72 & & & & \\
\hline
\end{tabular}

Sumber: Data diolah, 2018

Tabel 3. menunjukkan terdapat 72 data yang dianalisis yang diperoleh dari jumlah sampel sebanyak 24 perusahaan dikalikan dengan periode penelitian dari tahun 2015 hingga 2017 yaitu selama 3 tahun. Tabel tersebut juga menjelaskan nilai minimum, nilai maksimum, nilai rata-rata dan standar deviasi dari masingmasing variabel yang digunakan dalam penelitian ini.

Profitabilitas (Y). Hasil dari statistik deskriptif di Tabel 3. memperlihatkan jika nilai minimum profitabilitas sebesar $1,6 \%$ serta nilai maksmimum sebesar $30 \%$. Ini memperlihatkan jika besarnya profitabilitas dalam sampel penelitian berkisar diantara $1,6 \%$ sampai $30 \%$, pada rata-rata (mean) $10,443 \%$ di standar deviasi sebesar 6,3500\%. Profitabilitas terendah pada PT Sekar Bumi Tbk. tahun 2017 yaitu 1,6\% sedangkan profitabilitas tertinggi pada Handjaya Mandala Sampoerna Tbk. tahun 2016 yaitu 30\%.

Ukuran Perusahaan $\left(\mathrm{X}_{1}\right)$. Hasil statistik deskriptif pada Tabel 3. menunjukkan bahwa nilai minimum ukuran perusahan sebesar 25,796 dan nilai maksimum sebesar 32,108. Hal ini menunjukkan bahwa besarnya ukuran perusahan pada sampel penelitian ini berkisar antara 25,796 sampai 32,108 dengan rata-rata (mean) 28,79000 pada standar deviasi sebesar 1,560220. Ukuran perusahaan terendah pada Pyridam Farma Tbk. tahun 2017 yaitu 25,796 sedangkan ukuran perusahaan tertinggi pada PT Indofood Sukses Makmur Tbk. tahun 2017 yaitu 32,108.

Financial Leverage $\left(\mathrm{X}_{2}\right)$. Hasil statistik deskriptif pada Tabel 3 . menunjukkan bahwa nilai minimum financial leverage sebesar $7,1 \%$ dan nilai maksimum sebesar $63,2 \%$. Hal ini menunjukkan bahwa besarnya nilai financial leverage pada sampel penelitian ini berkisar antara 7,1\% sampai $63,2 \%$ dengan rata-rata (mean) 34,685\% pada standar deviasi sebesar 14,007\%. Nilai financial leverage terendah pada Industri Jamu \& Farmasi Sido Muncul Tbk. tahun 2015 yaitu $7,1 \%$, sedangkan nilai financial leverage tertinggi pada Sekar Bumi Tbk. tahun 2016 yaitu 63,2\%.

Manajemen Modal Kerja $\left(\mathrm{X}_{3}\right)$. Hasil statistik deskriptif pada Tabel 3. menunjukkan bahwa nilai minimum manajemen modal kerja sebesar 0,729 dan nilai maksimum sebesar 37,319. Hal ini menunjukkan bahwa besarnya nilai manajemen modal kerja pada sampel penelitian ini berkisar antara 0,729 sampai 37,319 dengan rata-rata (mean) 5,62278 pada standar deviasi sebesar 6,577094. 
Nilai manajemen modal kerja terendah di PT Delta Djakarta Tbk. tahun 2015 ialah 0,729 sedangkan nilai manajemen modal kerja tertinggi pada Sekar Bumi Tbk. tahun 2015 yaitu 37,319.

Tabel 4.

Hasil Uji Regresi Linier Berganda

\begin{tabular}{|c|c|c|c|c|c|c|}
\hline \multicolumn{2}{|c|}{ Model } & \multicolumn{2}{|c|}{$\begin{array}{l}\text { Unstandardized } \\
\text { Coefficients }\end{array}$} & \multirow{2}{*}{$\begin{array}{l}\text { Standardized } \\
\text { Coefficients } \\
\text { Beta }\end{array}$} & \multirow[t]{2}{*}{ Sig. } & \multirow{2}{*}{$\begin{array}{l}\text { Hasil Uji } \\
\text { Hipotesis }\end{array}$} \\
\hline & & $\mathbf{B}$ & Std. Error & & & \\
\hline \multirow[t]{6}{*}{1} & (Constant) & -.242 & .110 & & .031 & \\
\hline & Ukuran Prs & .015 & .004 & .368 & .000 & Diterima \\
\hline & Leverage & -.261 & .045 & -.577 & .000 & Diterima \\
\hline & Manj Modal K & .001 & . 001 & .128 & 202 & Ditolak \\
\hline & Adjusted $\mathrm{R}^{2}$ & & & & & .407 \\
\hline & Sig. F & & & & & .000 \\
\hline
\end{tabular}

Sumber: Data diolah, 2018

Tabel 4. merupakan hasil analisis bisa dibuat persamaan regresi linear berganda yaitu:

$\mathrm{Y}=-0,242+0,015 X_{1}-0,261 X_{2}+0,001 X_{3}+\mathrm{e}$

Keterangan:

$\mathrm{Y}=$ Profitabilitas

a $=$ Konstanta

$\mathrm{b}_{1-3}=$ Koefisien beta

$\mathrm{X}_{1}=$ Ukuran perusahaan

$\mathrm{X}_{2}=$ Financial leverage

$\mathrm{X}_{3}=$ Manajemen modal kerja

$\mathrm{e} \quad=$ Faktor gangguan pada observasi

Persamaan dari regresi linear berganda itu memperlihatkan arah masingmasing variabel bebas kepada variabel terikatnya, persamaan regresi itu bisa diuraikan berikut ini.

Nilai koefisien beta ukuran perusahaan sebesar 0,015 mempunyai nilai positif memperlihatkan adanya hubungan searah, jika ukuran perusahaan naik sebesar 1 persen, jadi profitabilitas meningkat sebesar 0,015 satuan dengan asumsi bahwa variabel bebas lainnya konstan atau serupa dengan nol.

Nilai koefisien beta financial leverage sebesar -0,261 mempunyai nilai negatif memperlihatkan adanya hubungan berlawanan, jika financial leverage naik sebesar 1 persen, jadi profitabilitas menurun sebesar 0,261 satuan dengan asumsi bahwa variabel bebas lainnya konstan atau serupa nol.

Nilai koefisien beta manajemen modal kerja sebesar 0,001 mempunyai nilai positif memperlihatkan adanya hubungan searah, jika manajemen modal kerja 
naik sebesar 1 persen, jadi profitabilitas meningkat sebesar 0,001 satuan dengan asumsi bahwa variabel bebas lainnya konstan atau serupa nol.

Tabel 5.

Hasil Uji Normalitas

\begin{tabular}{lll}
\hline Unstandardized Residual & & \\
\hline $\mathrm{N}$ & & 72 \\
Normal Parameters & Mean & .0000000 \\
& Std. Deviation & .04786778 \\
Most Extreme & Absolute & .147 \\
Differences & Positive & .147 \\
& Negative & -.059 \\
Kolmogorov-Smirnov Z & & 1.245 \\
Asymp.Sig (2-tailed) & & .090 \\
\hline Sumber: Data diolah, 2018 & &
\end{tabular}

Tabel 5. Menunjukan hasil uji normalitas. Data akan dikatakan berdistribusi normal apabila nilai koefisien Asymp. Sig (2-tailed) memperlihatkan angka lebih besar dibanding tingkat signifikansi dipakai $(0,05)$, Namun bila nilai dari koefisien Asymp. Sig (2-tailed) memperlihatkan angka lebih kecil dibanding tingkat signifikansi dipakai $(0,05)$ jadi data residual berdistribusi tidak normal. Berdasarkan Tabel 5. nilai Asymp. Sig (2-tailed) dari model persamaan diuji yaitu senilai 0,090 lebih besar dari tingkat signifikansi dipakai yaitu senilai 0,05 (0,090 $>0,05)$. Hal ini memperlihatkan jika data dipakai dalam penelitian memiliki distribusi normal.

Tabel 6.

Hasil Uji Autokorelasi

\begin{tabular}{llllll}
\hline Model & R & R Square & $\begin{array}{l}\text { Adjusted R } \\
\text { Square }\end{array}$ & $\begin{array}{l}\text { Std. Error of } \\
\text { the Estimate }\end{array}$ & $\begin{array}{l}\text { Durbin } \\
\text { Watson }\end{array}$ \\
\hline 1 & $0.657^{\mathrm{a}}$ & 0.432 & 0.407 & 0.048912 & 2.144 \\
\hline Sumber: Data diolah, (2018) & & & &
\end{tabular}

Tabel 6. memperlihatkan jika nilai Durbin-Watson (DW) sebesar 2,144. Didasarkan tabel DW pada tingkat signifikansi 0,05 kemudian jumlah variabel bebas sebanyak $3(\mathrm{k}=3)$ dan banyaknya jumlah sampel 72 jadi bisa diketahui nilai $\mathrm{dL}$ serta $\mathrm{dU}$. Kemudian Nilai $\mathrm{dL}=1,5323$ serta $\mathrm{dU}=1,7054$ sehiingga $4-\mathrm{dU}=$ 2,2946. Dikarenakan nilai DW tersebut berada diantara dU dan 4-dU (1,7054 < $2,144<2,2946)$ maka bisa disimpulkan jika dalam model regresi dipakai tidak ditemukan gejala autokorelasi.

Tabel 7.

Hasil Uji Multikolinearitas

\begin{tabular}{|c|c|c|c|c|c|c|}
\hline \multicolumn{2}{|l|}{ Model } & $\mathbf{X}_{1}$ & $\mathbf{X}_{2}$ & $\mathbf{X}_{3}$ & Tolerance & VIF \\
\hline 1 Correlations & $\mathrm{X}_{1}$ & 1.000 & -.039 & -.145 & .976 & 1.022 \\
\hline & $\mathrm{X}_{2}$ & -.039 & 1.000 & .376 & .858 & 1.165 \\
\hline & $X_{3}$ & -.145 & .376 & 1.000 & .842 & 1.188 \\
\hline
\end{tabular}

Sumber: Data diolah, 2018 
Tabel 7. memperlihatkan hasil uji multikolinearitas bisa diketahui nilai korelasi variabel ukuran perusahaan dengan variabel financial leverage sebesar $0,039(<0,90)$, nilai korelasi variabel ukuran perusahaan dengan variabel manajemen modal kerja sebesar $-0,145(<0,90)$, serta nilai korelasi variabel financial leverage dengan variabel manajemen modal kerja sebesar 0,376 $(<0,90)$. Setiap variabel yang digunakan yaitu ukuran perusahaan, financial leverage, dan manajemen modal kerja mempunyai nilai koefisien tolerance yg lebih besar dibanding 0,10 serta nilai VIF lbh kecil dari 10. Hal ini menunjukkan jika pada model regresi dipakai tidak terdapat gejala multikolinearitas antar variabel.

Tabel 8.

Hasil Uji Heteroskedastisitas

\begin{tabular}{lllllll}
\hline Model & \multicolumn{2}{l}{$\begin{array}{l}\text { Unstandardized } \\
\text { Coefficients }\end{array}$} & \multicolumn{2}{l}{$\begin{array}{l}\text { Standardized } \\
\text { Coefficients }\end{array}$} & t & Sig. \\
\cline { 3 - 5 } & $\mathbf{B}$ & Std. Error & Beta & \\
\hline $\mathbf{1}$ & (Constant) & .026 & .069 & & .381 & .704 \\
& Ukuran Prs & .001 & .002 & .051 & .443 & .659 \\
& Leverage & -.048 & .028 & -.209 & -1.709 & .092 \\
& Manj Modal K & -.011 & .000 & -.207 & -1.678 & .098 \\
\hline
\end{tabular}

Sumber: Data diolah, 2018

Tabel 8. memperlihatkan hasil uji heteroskedastisitas. Bisa dilihat jika nilai signifikansi pada variabel ukuran perusahaan $0,659(>0,05)$, variabel financial leverage senilai $0,092(>0,05)$, serta variabel manajemen modal kerja senilai $0,098(>0,05)$. Dikarenakan nilai dari signifikansi masing-masing variabel independen pada variabel absolute residual terdapat diatas 0,05 sehingga bisa disimpulkan jika data yang dipakai di penelitian ini tidak ada masalah heteroskedastisitas.

Koefisien determinasi bertujuan untuk mengukur sejauh mana kemampuan model regresi dalam menerangkan variasi variabel terikatnya (Ghozali, 2016:95). Dalam penelitian ini koefisien determinasi dilihat melalui nilai Adjusted $\mathrm{R}^{2}$. Adapun nilai dari Adjusted $\mathrm{R}^{2}$ pada penelitian ini telah disajikan pada Tabel 4 . dapat dilihat bahwa nilai Adjusted $\mathrm{R}^{2}$ sebesar 0,407 dimana memiliki arti bahwa 40,7 persen variasi perubahan profitabilitas dapat dijelaskan oleh variabel ukuran perusahaan, financial leverage, dan manajemen modal kerja. Sedangkan sisanya sebesar 59,3 persen dipengaruhi oleh variabel lain diluar dari model penelitian.

Uji t digunakan agar mengetahui pengaruh masing-masing variabel bebas secara parsial terhadap variabel terikat. Dilaksanakan uji statistik $\mathrm{t}$ dengan membandingkan hasil nilai signifikansi dengan $\alpha=0,05$

Pengaruh Ukuran Perusahaan $\left(\mathrm{X}_{1}\right)$ terhadap Profitabilitas $(\mathrm{Y})$. Didapatkan nilai signifikansi uji t pada variabel ukuran perusahaan pada $p$-value senilai 0,000 lebih kecil dari $\alpha=0,05$ dan nilai koefisien beta senilai 0,368 . Ini memperlihatkan 
jika ukuran perusahaan mempengaruhi positif serta signifikan terhadap profitabilitas, dan hipotesis pertama pada penelitian ini bisa diterima.

Pengaruh Financial Leverage $\left(\mathrm{X}_{2}\right)$ terhadap Profitabilitas $(\mathrm{Y})$. Didapatkan nilai signifikansi uji t pada variabel financial leverage pada $p$-value senilai 0,000 lebih kecil dari $\alpha=0,05$ dan nilai koefisien beta senilai -0,577. Ini memperlihatkan jika financial leverage mempengaruhi negatif serta signifikan terhadap profitabilitas, dan hipotesis kedua pada penelitian ini bisa diterima.

Pengaruh Manajemen Modal Kerja ( $\left.\mathrm{X}_{3}\right)$ terhadap Profitabilitas (Y). Didapatkan nilai signifikansi uji t pada variabel manajemen modal kerja pada $p$ value senilai 0,202 lebih besar dari $\alpha=0,05$ dan nilai koefisien beta senilai 0,128. Ini memperlihatkan jika manajemen modal kerja mempengaruhi positif serta tidak signifikan terhadap profitabilitas, dan hipotesis ketiga pada penelitian ditolak.

Uji kelayakan model dilaksanakan guna mengetahui apakah model dalam penelitian dibuat sudah memenuhi uji kelayakan model. Kemudian hasil dari pengujian kelayakan model pada penelitian ini sudah disajikan serta bisa dilihat jika nilai $p$-value (Sig. $F$ ) ialah 0,000 lebih kecil dibanding nilai $\alpha=0,05$. Ini memperlihatkan bahwa model penelitian tepat untuk dipergunakan memprediksi pengaruh variabel bebas pada variabel terikat.

Penelitian ini menemukan hasil bahwa ukuran perusahaan berpengaruh positif dan signifikan terhadap profitabilitas sehingga hipotesis pertama yang diajukan diterima. Ini menunjukkan bahwa meningkatnya profitabilitas perusahaan sektor industi barang konsumsi di BEI dipengaruhi oleh besarnya ukuran perusahaan selama periode 2015 hingga 2017.

Ukuran perusahaan merupakan gambar tentang perusahaan dalam memperlihatkan keberhasilan suatu perusahaan saat mengelola kegiatan operasional perusahaan. Besarnya ukuran perusahaan menunjukkan jika perusahaan ada pada kondisi baik dan mengalami perkembangan serta pertumbuhan yang baik pula. Perusahaan yang tumbuh dengan baik akan mempermudah perusahaan tersebut untuk memasuki pasar modal. Hal ini merupakan sinyal positif bagi perusahaan karena para investor dapat mempertimbangkan kestabilan nilai aset perusahaan sebagai pertimbangan dalam menentukan investasinya.

Semakin besar ukuran perusahaan yang ditunjukkan dengan semakin besar jumlah aktiva maka profitabilitas perusahaan akan meningkat. Hal ini disebabkan karena semakin besar total aktiva yang dimiliki suatu perusahaan maka semakin tinggi modal kerja yang dapat digunakan untuk memenuhi permintaan produk. Hal ini akan semakin memperluas pangsa pasar begitu juga laba perusahaan akan meningkat. Hasil penelitian ini sesuai dengan penelitian sebelumnya yang dilakukan oleh Ambarwati dkk. (2015), Daniel \& Sedana (2017), Sarwat (2017) serta Hantono (2017) yang menemukan jika ukuran perusahaan mempengaruhi positif serta signifikan pada profitabilitas.

Penelitian ini menemukan hasil jika financial leverage mempengaruhi negatif serta signifikan terhadap profitabilitas dan hipotesis kedua yang diajukan diterima. Ini menunjukkan bahwa menurunnya profitabilitas perusahaan sektor industi barang konsumsi di BEI dipengaruhi oleh besarnya financial leverage perusahaan selama periode 2015 hingga 2017. 
Leverage ialah kemampuan perusahaan dalam memenuhi kewajiban finansialnya baik pada jangka pendek ataupun jangka panjang, serta mengukur seberapa jauh perusahaan dibiayai memakai hutang. Financial Leverage menunjukkan proporsi atas penggunaan hutang untuk membiayai investasinya. Semakin besar hutang yang ditanggung perusahaan untuk memenuhi kebutuhan akan dananya maka semakin besar pula biaya yang harus dikeluarkan untuk pendanaan, baik untuk membayar biaya bunga ataupun untuk perantara keuangan. Tingginya risiko keuangan menyebabkan kemampuan perusahaan untuk mendapatkan keuntungan akan menurun.

Debt Ratio / Total Debts to Total Assets merupakan rasio yang digunakan untuk mengukur tingkat penggunaan hutang terhadap total aset yang dimiliki. Suatu perusahaan yang terlalu tinggi melakukan pendanaan aset dari hutang dapat menyebabkan semakin tinggi debt ratio yang berarti semakin tinggi risiko keuangannya sehingga kemampuan perusahaan untuk mendapatkan keuntungan akan menurun. Hasil penelitian ini sesuai dengan penelitian sebelumnya yang dilakukan oleh Alghusin (2015), Kartikasari \& Merianti (2016), serta Isık (2017) yang menemukan bahwa financial leverage berpengaruh negatif dan signifikan terhadap profitabilitas.

Penelitian ini menemukan hasil bahwa manajemen modal kerja berpengaruh positif dan tidak signifikan terhadap profitabilitas sehingga hipotesis ketiga yang diajukan ditolak. Ini menunjukkan bahwa profitabilitas perusahaan sektor industi barang konsumsi di BEI tidak dipengaruhi oleh manajemen modal kerja perusahaan selama periode 2015 hingga 2017.

Modal kerja dibutuhkan guna memberi dukungan kegiatan operasional perusahaan pada meningkatnya penjualan. Fluktuasi pada penjualan dapat diakibatkan oleh faktor musim serta siklus tersebut kemudian memberi pengaruh pada kebutuhan modal kerja. Semakin rendahnya manajemen modal kerja maka semakin tinggi penjualan yang tidak berhasil dilakukan dan semakin kecil keuntungan yang diraih perusahaan sehingga profitabilitas perusahaan akan menurun.

Hasil penelitian ini menunjukkan bahwa perputaran modal kerja tidak berpengaruh signifikan terhadap profitabilitas. Perusahaan memerlukan modal kerja guna memberi dukungan pada kegiatan operasional disaat terjadinya peningkatan penjualan. Kemudian fluktuasi pada penjualan, diakibatkan faktor musim serta siklus kemudian memberi pengaruh dalam kebutuhan modal kerja. Kemudian tidak berpengaruhnya modal kerja pada profitabilitas bisa disebabkan oleh perputaran modal kerja yang tidak tinggi dan kurang efektif penggunannya sehingga penjualan akan berkurang dan berdampak pada profitabilitas perusahaan yang tidak meningkat. Hasil penelitian ini sesuai dengan penelitian sebelumnya yang dilakukan oleh Meidiyustiani (2016), serta Santi \& Utiyati (2017).

Implikasi Teoritis. Hasil penelitian ini menyatakan bahwa ukuran perusahaan dan financial leverage berpengaruh terhadap profitabilitas. Hal ini menunjukkan bahwa tinggi rendahnya ukuran perusahaan yang diproksikan dengan logaritma natural dari total aset dan financial leverage yang diproksikan dengan debt ratio akan mempengaruhi kemampuan perusahaan dalam menghasilkan laba. Ukuran perusahaan yang berpengaruh positif terhadap 
profitabilitas sejalan dengan pendapat yang dikemukakan oleh Hantono (2017) bahwa perusahaan besar relatif lebih stabil dan lebih mampu menghasilkan laba dibandingkan dengan perusahaan kecil dan perusahaan dengan ukuran kecil pada umumnya mempunyai tingkat efisiensi yang rendah dan leverage financial yang lebih tinggi. Perusahaan dengan ukuran besar biasanya lebih mudah utk memperoleh dana pinjaman dlm jumlah yg cukup besar dan akan membanntu kegiatann operasional perusahaan serta hal ini mengakibatkan produktivitas perusahaann bertambah dan profitabilitas perusahaan juga bertambah (Putra \& Badjra, 2015).

Leverage yang berpengaruh negatif terhadap profitabilitas sejalan dengan teori dimana penggunaan hutang yang terlalu tinggi akan membahayakan perusahaan karena perusahaan akan masuk dalam kategori extreme leverage (hutang ekstrim) yaitu perusahaan terjebak dalam tingkat hutang yang tinggi dan sulit untuk melepaskan beban hutang tersebut (Fahmi, 2016:72). Semakin besar hutang yang ditanggung perusahaan maka perusahaan akan mengeluarkan biaya yang semakin besar pula untuk mendanai biaya bunga ataupun untuk perantara keuangan. Tingginya risiko keuangan menyebabkan kemampuan perusahaan untuk mendapatkan keuntungan akan menurun.

Implikasi Praktis. Hasil penelitian ini dapat menjadi pertimbangan bagi perusahaan dalam pengambilan keputusan investasi dan pendanaan. Perusahaan dapat mempertimbangkan berapa jumlah hutang dan aktiva yang harus dimiliki oleh perusahaan sehingga kemampuan perusahaan dalam meningkatkan profit akan semakin tinggi. Bagi investor, hasil dari penelitian ini dapat dijadikan dasar dalam pengambilan keputusan investasi di perusahaan sektor industri barang konsumsi di BEI.

\section{SIMPULAN DAN SARAN}

Simpulan dari penelitian ini yaitu ukuran perusahaan berpengaruh positif dan signifikan terhadap profitabilitas. Semakin besar ukuran perusahaan yang ditunjukkan dengan semakin besar jumlah aktiva maka profitabilitas perusahaan akan meningkat. Financial leverage berpengaruh negatif dan signifikan terhadap profitabilitas. Semakin besar hutang yang ditanggung perusahaan maka semakin tinggi risiko keuangannya yang menyebabkan profitabilitas perusahaan akan menurun. Manajemen modal kerja tidak berpengaruh signifikan terhadap profitabilitas. Tidak berpengaruhnya modal kerja pada profitabilitas bisa disebabkan oleh berputarnya modal kerja yang rendah serta tidak efektif pemakaiannya sehingga penjualan akan berkurang dan berdampak pada profitabilitas perusahaan yang tidak terjadi peningkatan.

Saran dari penelitian yaitu bagi perusahaan hendaknya memperhatikan ukuran perusahaan yang dapat dilihat dari jumlah aktiva perusahaan sehingga perusahaan diharapkan dapat meningkatkan profitabilitas perusahaan. Hal ini dikarenakan semakin besar total aset yang dimiliki suatu perusahaan maka semakin tinggi modal kerja yang dapat digunakan untuk memenuhi permintaan produk sehingga profit perusahaan akan meningkat. Bagi penanam modal, diharapkan penelitian ini bisa memberikan infomasi pada suatu pertimbangan saat memutuskan serta menentukan investasi dilaksanakan. Penelitian ini hanya 
menggunakan tiga variabel yaitu ukuran perusahaan, financial leverage, dan manajemen modal kerja untuk menjelaskan pengaruhnya terhadap profitabilitas, dan hanya memakai rentan waktu tiga tahun. Oleh sebab itu, peneliti kedepannya bisa melaksanakan penelitian sama, tapi dengan penambahan variabel dan memiliki pengaruh pada profitabilitas yang tidak dijelaskan dalam penelitian ini (59,3 persen). Kemudian lebih memperluas lagi ruang lingkup serta jenis perusahaan berbeda dan hasil yang didapat penelitian bisa dijadikan pedoman untuk melaksanakan penelitian kemudiannya serta bisa digunakan untuk sumber informasi masyarakat luar.

\section{REFERENSI}

Al-Jafari, M. K., \& Al Samman, H. (2015). Determinants of Profitability: Evidence from Industrial Companies Listed on Muscat Securities Market. Review of European Studies, 7(11), 303-311. https://doi.org/10.5539/res.v7n11p303

ALghusin, N. A. S. (2015). Do Financial Leverage, Growth and Size Affect Profitability of Jordanian Industrial Firms Listed? International Journal of Academic Research in Business and Social Sciences, 5(4), 385-398. https://doi.org/10.6007/ijarbss/v5-i4/1580

Ambarwati, N. S., Yuniarta, G. A., \& Sinarwati, N. K. (2015). Pengaruh Modal Kerja, Likuiditas, Aktivitas Dan Ukuran Perusahaan Terhadap Profitabilitas Pada Perusahaan Manufaktur Yang Terdaftar Di Bursa Efek Indonesia. EJournal S1 Ak Universitas Pendidikan Ganesha, 3(1), 11.

Barus, A. C., \& Leliani. (2013). Analisis Faktor-Faktor yang Mempengaruhi Profitabilitas pada Perusahaan Manufaktur yang Terdaftar di Bursa Efek Indonesia. Jurnal Wira Ekonomi Mikroskli, 3(2), 73-81. Retrieved from https://mikroskil.ac.id/ejurnal/index.php/jwem/article/view/207

Chen, S., \& Oetomo, H. W. (2015). Pengaruh Leverage, Likuiditas, dan Perputaran Modal Kerja Terhadap Profitabilitas. Jurnal IImu Dan Riset Manajemen, 4(10), 1-21.

Daniel, W., \& Sedana, I. B. P. (2017). Pengaruh Ukuran Perusahaan, Suku Bunga dan Struktur Modal Terhadap Profitabilitas. E-Jurnal Manajemen Universitas Udayana, 6(12), 6913-6931. Retrieved from https://media.neliti.com/media/publications/252483-pengaruh-ukuranperusahaan-suku-bunga-da-963a30cd.pdf

Dewi, A. A. A. K., \& Badjra, I. B. (2017). Pengaruh Profitabilitas, Aktiva Tidak Berwujud, Ukuran Perusahaan, dan Struktur Modal Terhadap Nilai Perusahaan. E-Jurnal Manajemen Universitas Udayana, 6(4), 2161-2190.

Fahmi, I. (2016). Pengantar Manajemen Keuangan. Bandung: Alfabeta.

Fareed, Z., Ali, Z., Shahzad, F., Nazir, M. I., \& Ullah, A. (2017). Determinants of Profitability: Evidence from Power and Energy Sector. Studia Universitatis 
Babe-Bolyai Oeconomica, 61(3), 59-78. https://doi.org/10.1515/subboec2016-0005

Ghozali, I. (2016). Aplikasi Analisis Multivariative dengan Program SPSS. Semarang: Badan Penerbit Universitas Diponegoro.

Hantono, T. S. H. (2017). Pengaruh Likuiditas, Ukuran Perusahaan, Leverage Terhadap Profitabilitas Dengan Corporate Social Responsibility Sebagai Variabel Intervening Pada Perusahaan Consumer Goods Yang Terdaftar Di Bursa Efek Indonesia. Jurnal Manajemen Bisnis Dan Inovasi, 4(3), 131-143.

Hermuningsih, S. (2013). Pengaruh Profitabilitas, Growth Opportunity, Struktur Modal Terhadap Nilai Perusahaan Pada Perusahaan Publik Di Indonesia. Jurnal Buletin Ekonomi Moneter Dan Perbankan, 16(2), 127-148.

Hidayat, W., \& Wahyuati, A. (2015). Analisis Faktor-Faktor Yang Mempengaruhi Profitabilitas. Jurnal Ilmu Dan Riset Manajemen, 4(6), 1-17.

Iqbal, A., \& Zhuquan, W. (2015). Working Capital Management and Profitability Evidence from Firms Listed on Karachi Stock Exchange. International Journal of Business and Management, 10(2), 231-235. https://doi.org/10.5539/ijbm.v10n2p231

Isık, O. (2017). Determinants of Profitability: Evidence from Real Sector Firms Listed in Borsa Istanbul. Business and Economics Research Journal, 4(8), 689-698. https://doi.org/10.20409/berj.2017.76

Jacob, M. G. (2016). Determinants of Profitability of Agricultural Firms Listed At the Nairobi Securities Exchange, Kenya. International Journal of

Economics, Commerce and Management United Kingdom, 4(9), 225-235. Retrieved from http://ijecm.co.uk/

Kartikasari, D., \& Merianti, M. (2016). The Effect of Leverage and Firm Size to Profitability of Public Manufacturing Companies in Indonesia. International Journal of Economics and Financial Issues, 6(2), 409-413. https://doi.org/10.1093/acprof:oso/9780199378111.001.0001

Lazar, S. (2016). Determinants of Firm Performance: Evidence from Romanian Listed Companies. Review of Economic and Business Studies, 9(1), 53-69. https://doi.org/10.1515/rebs-2016-0025

Lokollo, A. (2013). Pengaruh Manajemen Modal Kerja dan Rasio Keuangan Terhadap Profitabilitas pada Industri Manufaktur yang Terdaftar di Bursa Efek Indonesia Tahun 2011. Diponegoro Jurnal of Accounting, 2(2), 1-13. https://doi.org/10.1098/rspb.2007.0169

Margaretha, F., \& Supartika, N. (2016). Factors Affecting Profitability of Small Medium Enterprises (SMEs) Firm Listed in Indonesia Stock Exchange. Journal of Economics, Business and Management, 4(2), 132-137. https://doi.org/10.7763/joebm.2016.v4.379 
Meidiyustiani, R. (2016). Pengaruh Modal Kerja, Ukuran Perusahaan, Pertumbuhan Penjualan dan Likuiditas Terhadap Profitabilitas Pada Perusahaan Manufaktur Sektor Industri Barang Konsumsi yang Terdaftar di Bursa Efek Indonesia (BEI) periode tahun 2010-2014. Jurnal Akuntansi Dan Keuangan, 5(2), 161-179. Retrieved from http://fe.budiluhur.ac.id/wpcontent/uploads/2017/03/52c-Rinny-fix.pdf

Mwangi, M., \& Murigu, J. W. (2015). The Determinants of Financial Performance in General Insurance Companies in Kenya. European Scientific Journal, ESJ, 11(1), 288-297.

Nejad, D. A., Bandarian, A., \& Ghatebi, M. (2015). Effect of Working Capital Management on The Profitability of Listed Companies in Tehran Stock Exchange. Journal of Life Science and Biomedicine, 5(1), 21-25.

Pangestuti, C. D. A., \& Oetomo, H. W. (2016). Pengaruh Perputaran Modal Kerja, Ukuran Perusahaan, Operating Leverage, Financial Leverage Terhadap Profitabilitas. Ilmu Dan Riset Manajemen, 5(7), 1-18.

Puspita, D. A., \& Hartono, U. (2018). Pengaruh Perputaran Modal Kerja, Ukuran Perusahaan, Leverage dan Likuiditas Terhadap Profitabilitas Perusahaan Animal Feed di BEI Periode 2012-2015. Jurnal Ilmu Manajemen, 6(2009), $1-8$.

Putra, A. A. W. Y., \& Badjra, I. B. (2015). Pengaruh Leverage, Pertumbuhan Penjualan dan Ukuran Perusahaan Terhadap Profitabilitas. E-Journal Manajemen Unud, 4(7), 2052-2067.

Rudin, M., Nurdin, D., \& Fattah, V. Y. (2016). The Effect of Liquidity and Leverage on Profitability of Property and Real Estate Company in Indonesian Stock Exchange. International Journal of Social Sciences and Management, 3(4), 300-304. https://doi.org/10.3126/ijssm.v3i4.15964

Santi, O. H., \& Utiyati, S. (2017). Pengaruh Perputaran Modal Kerja, Current Ratio, Dan Leverage Operasi Terhadap Profitabilitas. Jurnal Ilmu Dan Riset Manajemen, 6(8), 1-18.

Sariyana, B. M., Yudiaatmaja, F., \& Suwendra, I. W. (2016). Pengaruh Perputaran Modal Kerja Dan Likuiditas Terhadap Profitabilitas ( Studi Pada Perusahaan Food and Beverages ). E-Journal Bisma Universitas Pendidikan Ganesha, $4(1), 1-10$.

Sartono, A. (2010). Manajemen Keuangan Teori dan Aplikasi (Edisi 4). Yogyakarta: BPFE Yogyakarta.

Sarwat, S. (2017). Impact of Working Capital Management On The Profitability of Firms: Case of Pakistan's Cement Sector. Journal of Advanced Management Science, 5(3), 238-244.

Sritharan, V. (2015). Does Firm Size Influence on Firm's Profitability? Evidence From Listed Firms of Sri Lankan Hotels and Travels Sector. Research 
Journal of Finance and Accounting, 6(6), 201-207.

Sugiyono. (2016). Statistika Untuk Penelitian. Bandung: Alfabeta.

Suryaputra, G., \& Christiawan, Y. J. (2016). Pengaruh Manajemen Modal Kerja, Pertumbuhan Penjualan dan Ukuran Perusahaan Terhadap Profitabilitas Pada Perusahaan Properti dan Real Estate Yang Terdaftar di Bursa Efek Indonesia ( BEI ) Tahun 2010-2014. Business Accounting Review, 4(1), 493-504. https://doi.org/10.1038/nrendo.2011.14

Wiagustini, N. L. P. (2014). Dasar-Dasar Manajemen Keuangan. Denpasar: Udayana Press.

Winarno, Hidayati, L. N., \& Darmawati, A. (2015). Faktor-Faktor Yang Memengaruhi Profitabilitas Perusahaan Manufaktur Yang Listed Di Bursa Efek Indonesia. Jurnal Economia, 11(2), 143-149.

https://doi.org/10.21831/economia.v11i2.7957

Yanthi, N. D., \& Sudiartha, G. M. (2017). Pengaruh Likuiditas dan Perputaran Modal Kerja terhadap Profitabilitas pada Perusahaan Manufaktur Sektor Industri Barang Konsumsi. E-Jurnal Manajemen Universitas Udayana, 6(9).

Yazdanfar, D. (2013). Profitability Determinants Among Micro Firms: Evidence From Swedish Data. International Journal of Managerial Finance, 9(2), 150-160. https://doi.org/10.1108/17439131311307565

Yazdanfar, D., \& Öhman, P. (2014). The Impact of Cash Conversion Cycle on Firm Profitability: An Empirical Study Based on Swedish Data. International Journal of Managerial Finance, 10(4), 442-452. 